New Zealand journal of industrial relations. 1986, 11, 191-192

\title{
COMMENT
}

\section{The activity of employer unions in perspective}

\author{
Raymond E Taylor* and Bevan R Greenslade+
}

As two of the employer representatives thanked by the authors of the article The inactivites of employer unions by P Brosnan, P Walsh and P Rowe for their advice, we are prevented by modesty (and other sentiment) from bearing the burden of any credit for its contents and interpretations.

"Inactivities" reports on a student's research field work carried out four years ago into employer unions; it was to that student we proffered our advice. The two academic authors (Brosnan. Walsh) subsequently imposed their own presumptions and interpretations upon the data.

The article cites Wood (1982) who dismissed as naive the belief that to study employers is to be seen as supporting them. There need be no fear of that in the article.

Brosnan et al. appear to assume that because workers' unions are primary bodies constituted by and functioning under the Industrial Relations Act, employer unions are likewise primary bodies with comparable functions. This is not the case.

Employer unions are always and invariably constituted as ancillary to primary employer bodies and are created for the purpose of the statute to faciliate the conduct of collective bargaining on behalf of the employers in the industry concerned.

The primary employer body is typically an incorporated society, may be national or regional in scope, and is organised to serve employers either individually or in one or more industry group. The employer union runs in parallel with the primary body, often with the same office bearers and with a common membership, but functioning strictly for the purpose of award negotiation.

It is the primary employer body which provides the membership services and activities for employers, employs the staff, and often fully funds the operations of the employer union.

The term "bi-functional" is used by Brosnan et al. to describe employer unions which operate out of the same office as a trade association. This distinction is quite unhelpful, since all employer unions are bi-functional in the sense of operating in association with a primary employer body; but the registered offices may or may not be the same. The location of the registered office of an employer union is a matter of custom or convenience for each industry to decide, and no particular conclusions can be drawn.

Brosnan et al. admit facts about employer unions as momentous conclusions, as the following references show: "a great many are not independent organisations in their own right ..." p.144; "most ... do not operate independently" p.144; "the subordinate nature ... was very plain" p.146. Yet the authors presume to castigate employer unions for their alleged "inactivities" and "lack of independence".

The abstract states: "It is found that many employer unions are completely inactive". The actual count was 18 out of 122 union as Table 1 shows.

Reasons for inactivity were not explored by the authors. Had this been done it might have been discovered that worker union activity in the particular districts/industries might also have been commensurately low. Sometimes union registrations are preserved despite low industrial activity as an insurance policy for the future.

The abstract also states: "Those that are active are little inclined to hold meetings and few provide a range of services to members". Given that the essential function of employer unions 
is to facilitate the conduct of award negotiations, it is not surprising that meetings and activity tend to be concentrated on the award time. Yet half of the employer unions also held meetings outside of the award time (Table 4, Brosnan et al.) and 70 percent held meetings of their industrial committees throughout the year (Table 5, Brosnan et al.). Nothing is said of the meetings, services and membership activities of the primary employer bodies with which the employer unions are associated, be they regional employers associations or trade associations.

The abstract goes on to state: "The most active employer unions are those attached to a trade association and/or with their own office separate from the New Zealand Employers Federation".

This assertion is not supported by the data. The $X^{2}$ analysis of their Tables 1 and 2 discloses no significant difference in "activeness" (even assuming it can be scored by the measures chosen) between employer unions located at NZEF and those located elsewhere. Likewise there is no significant difference in "activeness" between employer unions housed with a trade association and those housed elsewhere.

Not only do the conclusions not follow from the data, but also the tone of the interpretative comments invites the imputation of animus against organisations in general and the New Zealand Employers Federation in particular.

The authors acknowledge that NZEF as the central organisation of employers does provide to employers "a more professional service" and a more active stand in negotiation, through staff who bring "a range of relevant experience in industrial matters".

However, they then assert that NZEF staff, rather than the membership, play the "key role". Further, the authors complain of the "dominance of NZEF which spoon-feeds many employer unions" (p.155) as a near monopoly which they claim gives the Federation considerable control over the employers' position in wage negotiations (p.150). Brosnan et al. even see Trade Associations as allowing an alternative perspective to that of the NZEF to be heard in employer circles, although they warn that Trade Associations do not "escape the influence of the Federation entirely" (p.148).

These gratuitous comments might be interpreted at best as a misunderstanding of the way that primary employer bodies relate to each other and at worst a mischievous attempt to divide them.

It is simply not true that the NZEF is a monolithic monopoly which stands over other employer bodies. The fact is that it is comprised of 4 autonomous Regional Employers' Associations and 65 national Trade Associations, each of which is represented on the Federation's National Council and each of which participates in forming the industrial policies of the Federation.

In sum, the research is weak, the comment intuitive and the conclusions do not follow from either the research or the comment. The article fails to support its implicit thesis that NZEF is somehow at once omnipotent and impotent. It is definitely an indefinite article.

Table 1: The activity of employer unions

\begin{tabular}{lrrrc}
\hline Location & Active & Inactive & Total & Percent Active \\
\hline NZEF & 37 & 5 & 42 & 88.10 \\
Not at NZEF & 67 & 13 & 80 & 83.75 \\
Total & 104 & 18 & 122 & 85.25
\end{tabular}

